\title{
Effect of Arterial Oxygen Tension on Cerebral Blood Flow at Different Levels of Arterial $\mathbf{P G O}_{2}$
}

Cerebral blood flow is closely correlated to carbon dioxide tension of arterial blood over a wide range of $\mathrm{PaCO}_{2}{ }^{1}$. Oxygen exerts a vaso-constricting effect at high tensions, while a reduction of arterial $\mathrm{PO}_{2}$ produces no effect until a critical level of $30-50 \mathrm{~mm} \mathrm{Hg}$ is attained ${ }^{2}$. The effects of combined alterations in arterial oxygen and carbon dioxide tensions on cerebral blood flow, however, are largely unknown although of considerable clinical and theoretical interest. In the present study the influence of different arterial $\mathrm{PCO}_{2}$ tensions on the cerebrovascular responsiveness to alterations of arterial $\mathrm{PO}_{2}$ between $50-$ $140 \mathrm{~mm} \mathrm{Hg}$ was investigated.

Methods. The experiments were performed in 31 cats, anaesthetized with nembutal $(30 \mathrm{mg} / \mathrm{kg}$ body weight, i.p.). After tracheotomy the animals were curarized and ventilated with a Starling pump. 15 animals (group I) were ventilated at a normal rate and normal tidal volume with $\mathrm{N}_{2} / \mathrm{O}_{2}$ mixtures of different oxygen content. $\mathrm{PaO}_{2}$ in this group was in the range of $55-140 \mathrm{~mm} \mathrm{Hg}$; $\mathrm{PaCO}_{2}$ was $28.2 \pm 1.83$ S.D. In 16 experiments (group II) $3-5 \% \quad \mathrm{CO}_{2}$ was added to the above gas mixtures. $\mathrm{PaCO}_{2}$ varied between 35.5 and $72.5 \mathrm{~mm} \mathrm{Hg}$ (mean $47.33 \pm 12.6$ S.D.). $\mathrm{PaO}_{2}$ was in the range between 50 $140 \mathrm{~mm} \mathrm{Hg}$.

Arterial blood pressure (Statham pressure gauge transducers) and end-expiratory $\mathrm{CO}_{2}$ (IR analyser) were continuously recorded. Arterial $\mathrm{PO}_{2}, \mathrm{PCO}_{2}$ and $\mathrm{pH}$ were determined according to the micro-method of AsTRUP. Cardiac output was measured by thermodilution technique. Blood flow through forebrain, cerebellum and brain stem was determined under steady-state conditions no correlation between $\mathrm{PaO}_{2}$ (varying between $55-140 \mathrm{~mm}$ $\mathrm{Hg}$ ) and blood flow is seen; in hypercapnia, however, a significant negative correlation between $\mathrm{PaO}_{2}$ and blood flow through forebrain, cerebellum and brain stem is observed.

It is concluded from these data that the response to combined alterations of $\mathrm{PaO}_{2}$ and $\mathrm{PaCO}_{2}$ is not simply additive. Similar results were obtained by SHapiro et al. ${ }^{4}$ in man. Agnol I et al. ${ }^{5}$ observed that hypoxia prevents the adaption of $\mathrm{CBF}$ and $\mathrm{CSF} p \mathrm{H}$ to chronic hypercapnia. These authors propose that hypoxia might interfere with active transport mechanisms involved in the regulation of the extracellular $\mathrm{pH}$ of the central nervous system. Our findings seem to constitute another aspect of the same phenomenon, namely an increased sensitivity to hypoxia under hypercarbia.

Zusammenfassung. Die Wirkung des arteriellen $\mathrm{O}_{2}$ Partialdruckes auf die Durchblutung des Grosshirns, Kleinhirns und Hirnstammes bei normalen und erhöhten $\mathrm{CO}_{2}$-Partialdrucken im arteriellen Blut wird an der anaesthesierten Katze untersucht. Die Wirkung des $\mathrm{PaO}_{2}$ ist von der Höhe des $\mathrm{PaCO}_{2}$ abhängig.

H. Flohr, W. PÖLL and M. Brock

Physiologisches Institut der Universität Bonn, D-53 Bonn (Germany), und.

Neatochinugische Klinik der Universität Mainz, 30 December 1969.

Partial correlation coefficients between $\mathrm{PaO}_{2}, \mathrm{PaCO}_{2}$ mean arterial blood pressure (BP) and blood flow through forebrain (CBFP), cerebellum $(\mathrm{CBFC})$ and brain stem (CBIs)

\begin{tabular}{|c|c|c|c|c|c|c|}
\hline & Group & $\mathrm{PaCO}_{2}$ & $B P$ & $C B F_{P}$ & $\mathrm{CBli}^{\circ}$ & CJBFs \\
\hline \multirow[t]{2}{*}{$\mathrm{PaO}_{2}$} & I & 0.0702 & 0.0092 & -0.4242 & -0.2515 & -0.1330 \\
\hline & II & -0.3878 & 0.1080 & $--0.7161^{\circ}$ & $-0.6186^{\circ}$ & $-0.5612^{\circ}$ \\
\hline \multirow[t]{2}{*}{$\mathrm{PaCO}_{2}$} & I & - & -0.0969 & $0.8151^{\circ}$ & $0.8178^{\circ}$ & 0.9006 \\
\hline & $\mathrm{II}$ & - & 0.0892 & 0.3661 & $0.5881^{a}$ & 0.1133 \\
\hline \multirow[t]{2}{*}{$\mathrm{BP}$} & $I$ & - & - & -0.1860 & -0.3273 & -0.3105 \\
\hline & II & - & - & -0.0614 & 0.1301 & 0.0183 \\
\hline
\end{tabular}

Significant correlations: a $0.05>p>0.01 .{ }^{\circ} 0.01>p>0.001 . " p<0.001$.

of $\mathrm{PaO}_{2}, \mathrm{PaCO}_{2}$, mean arterial blood pressure, and cardiac output by means of the particle distribution technique ${ }^{3}$. In group II the determination of $\mathrm{CBF}$ was carried out after a period of $35-40 \mathrm{~min}$ of $3-5 \% \mathrm{CO}_{2}$ inhalation.

Results. The results of multiple regression analysis of the data are summarized in the Table. Cerebrovascular responsiveness to changes in $\mathrm{PaO}_{2}$ in hypercapnia differs from that observed under normocapnia. In normocapnia
1 M. Reivich, Ain. J. Physiol. 206, 25 (1964).

2 S. Shimojyo, P. Scheinberg, K. Kogure and O. M. Reinmuxh, Neurology 18, 127 (1968).

3 H. Fionr, Pflugers Arch, ges. Physiol. 302, 268 (1968).

4 W. Shapiro, A. J. Wasserman and I. L. Patterson JR., Circulation Res. 19, 903 (1966).

5 H. Agnoli, N. Battistini, M. Nardini, S. Passero and C. Fieschi, in Ceyebral Blood Flow (Eds. M. Brock, C. Fieschi, D. H. Ingvar, N. H. LASSEN and K Schürman; Springer Verlag, Berlin, Heidelberg, New York 1969), p. 79.

\section{Chronic Effects of Nicotine on Rat Gastric Secretion}

Tobacco smoking has been implicated as a contributory factor in the aetiology, and reduced healing, of peptic ulcers ${ }^{1,2}$. Furthermore, nicotine has been shown to increase the ulcerogenic potential of histamine in $\operatorname{dogs}^{3}$ and the histamine-forming capacity of the rat stomach ${ }^{4}$. These facts suggest that nicotine and smoking may increase gastric acid and pepsin production, however, secretory data in the literature are contradictory ( ${ }^{5}$ review). We have recently shown that acute doses of nicotine depress gastric secretion ${ }^{6,7}$, but this may not be directly applicable to the condition resulting from chronic alkaloid exposure. Reported here are the effects of chronic nicotine 